2,249 persons were all exposed to 5 rads, and in practice their exposure was on average much lower, the exposed group would still be less than $2 \%$ of the minimum size (in man-years) to permit detection of radiation-induced leukaemia and an even smaller fraction of the size (in man-generations) required for detection of a mutation attributable to the increased radiation.

\section{Summary and Conclusions}

In order to detect radiation effects by a population study it is, of course, essential that the population be large enough for the radiation effects to be statistically significant. For exposure of man to low doses of radiation at low dose rates the minimum population size to permit detection of radiation-induced leukaemia is many tens of thousands of man-years; for detection of dominant mutations attributable to the increased radiation the necessary population (in man-generations), as estimated from mouse data, is even larger. Exposed populations which have been surveyed so far are smaller than the minimum theoretical size and would need to be studied for an impracticably long time before either a mutation attributable to the increased radiation at a single locus or radiation-induced leukaemia could be detected. Stevenson (1957), in his examination of this problem, also concluded that it appeared unlikely that populations could be found of sufficient size to permit detection of mutations induced by background radiation.

In conclusion it should be emphasized that, in addition to the difficulty of fulfilling the requirement for a minimum popula- tion size, if a population study were undertaken to detect radiation effects additional practical problems are likely to be encountered in setting up a satisfactory control population (Grünberg, 1964) and in assessing mean annual doses.

\section{REFERENCES}

Buck, C. (1959). Science, 129, 1357.

Court Brown, W. M., and Doll, R. (1957). Spec. Rep. Ser. med. Res. Coun. (Lond.), No. 295.

- Spiers, F. W., Duffy, B. J., and McHugh, M. J. (1960). Brit. med. 7., 1,1753 .

Craig, L., and Seidman, H. (1961). Blood, 17, 319.

Grahn, D., and Kratchman, J. (1963). Amer. F. hum. Genet., 15, 329.

Greenslade, E. (1965). Radiological Protection Service, Personal communication.

Grüneberg, H. (1964). Nature (Lond.), 204, 222.

Lejeune, J., Turpin, R., and Rethore, M. O. (1960). IXth International Congress of Radiology (Proceedings), p. 1089.

Lewis, E. B. (1957). Science, 125, 965.

Lindell, B. (1960). The Use of Vital and Health Statistics for Genetic and Radiation Studies (A/AC/.82/Seminar).

- and Dobson, R. L. (1961). Wld Hlth Org. Publ. Hlth Pap., No. 6.

Marloy, W. G. (1965). Authority Health and Safety Branch, U.K. Atomic Energy Authority, Personal communication.

Medical Research Council (1956). The Hazards to Man of Nuclear and Allied Radiation (Cmd. 9780). H.M.S.O., London.

Penrose, L. S. (1957). Effect of Radiation on Human Heredity, p. 101. W.H.O., Geneva.

Sowby, D. (1964). Personal communication.

Stevenson, A. C. (1957), Effect of Radiation on Human Heredity, p. 125. W.H.O., Geneva.

(1964). Personal communication.

United Nations (1962). Report of the United Nations Scientific Committee on the Effects of Atomic Radiation, p. 14. New York.

\title{
Hepatic Folate in Man
}

\author{
I. CHANARIN,* M.B., CH.B., M.D., D.C.P.; M. HUTCHINSON,† B.A., B.SC. ; ANNE MCLEAN, $\ddagger$ PH.D. \\ MARGARET MOULE,§ M.S.
}

Brit. med. F., 1966, 1, 396-399

Tests of folic-acid function are widely used in the investigation of patients with megaloblastic anaemia. These tests are the urinary excretion of formiminoglutamic acid and the direct assay of the serum (or whole blood) concentration of various forms of folate by microbiological assay. Results with these tests have been reviewed in a recent symposium at the Royal Society of Medicine (Herbert, 1964 ; Chanarin, 1964).

Abnormal results with both these tests are frequent in hospital patients who are haematologically normal, and it is uncertain whether these abnormal values indicate subclinical folate deficiency or merely the unsatisfactory nature of the tests. The purpose of this study was to correlate the results of these tests of folic-acid function with direct assay of the amount of folic acid in the tissues. The liver is the most satisfactory tissue for this purpose, since it contains most of the folates in the body and is the site of the important synthetic reactions involving the folate coenzymes. Donaldson and Keresztesy (1959) have found that hepatic folate in the horse is 5-methyltetrahydropteroyl-monoglutamate. This paper also reports observations on the nature of the folate compounds in human liver.

\section{Materials and Methods}

Observations were made on 26 patients admitted to the surgical wards with a variety of disorders (see Table), and who were all undergoing a laparotomy. The day before operation a blood sample was obtained for a full blood count, including enumeration of five-lobed neutrophils, and for the microbiological assay of the levels of serum folate and vitamin $B_{12}$. Fifteen grammes of 1 -histidine-mono- $\mathrm{HCl}$ was given orally and urine collected for eight hours for the estimation of formiminoglutamic-acid excretion. At laparotomy a small liver biopsy was taken by the surgeon. The liver was either processed immediately for assay of its folate content or stored in a dry, sealed, container at $-20^{\circ} \mathrm{C}$. for a few days before processing. Liver biopsies were also obtained from two patients with megaloblastic anaemia due to folic-acid deficiency. In both patients the cause of the megaloblastic anaemia was excessive alcohol consumption associated with a poor diet. Two samples of liver obtained at necropsy were also studied.

All the surgical patients in our study were truly volunteers. The procedure was explained to them some days before the operation, and their willingness to co-operate was obtained. Further, the consent of the surgeon in charge of the patient was also obtained, and the taking of the very small biopsy was entirely at the discretion of the surgeon at the operationand indeed in some cases this was not obtained.

\footnotetext{
* Senior Lecturer in Haematology.

+ Medical Student.

$¥$ Member of the Scientific Staff.

Member of the Scientific Staff.

M.R.C. Experimental Haematology Research Unit and Department of M.R.C. Experimental Haematology Research Unit and Department of
Haematology, The Wright-Fleming Institute of Microbiology, St. Mary's Hospital Medical School, London.
} 
Observations in 26 Patients Undergoing Laparotomy and Two with Megaloblastic Anaemia

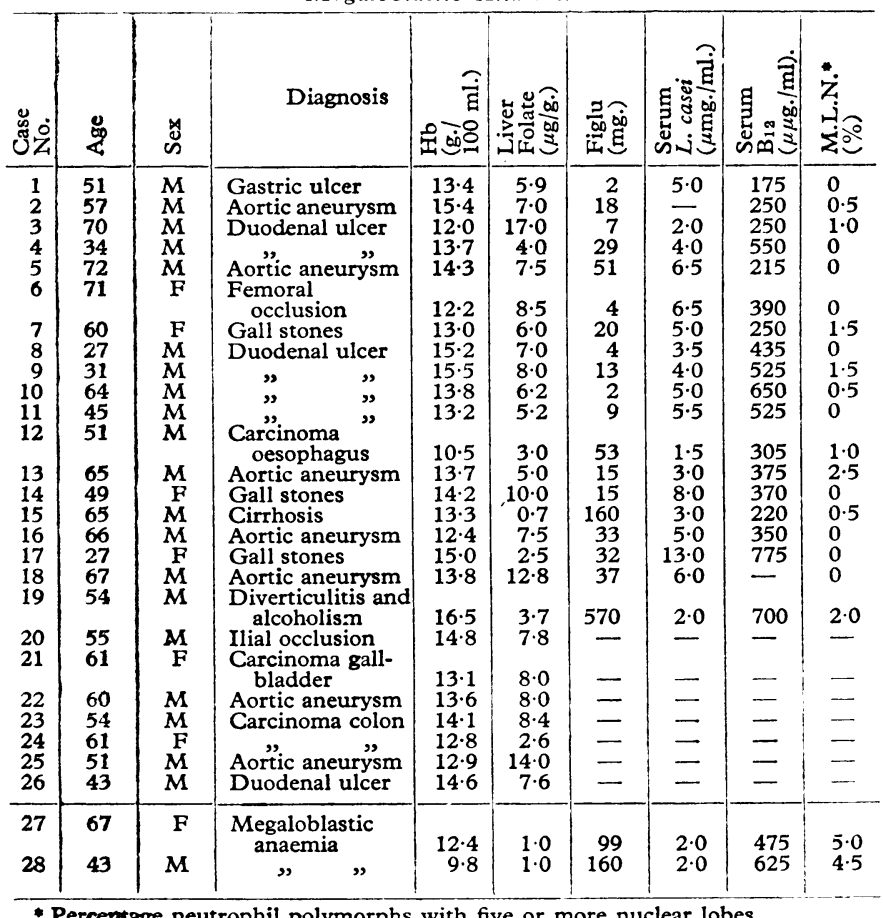

- Percentage neutrophil polymorphs with five or more nuclear lobes.

\section{Preparation of Liver Sample for Folate Assay}

Preliminary studies of methodology were carried out as described elsewhere (Bennett, Berry, Chanarin, and Ardeman, 1964). These showed that the maximum values were obtained in the case of human liver when 1 part of liver was homogenized and heated in 500 parts of $1 \%$ potassium ascorbate buffer at pH 6. The same conclusion was reached by Romine (1960) in assaying human liver obtained at necropsy. The highest values were obtained with aliquots of liver of about $15 \mathrm{mg}$. Whereas with rat liver incubation of the liver homogenate at $37^{\circ} \mathrm{C}$. at alkaline $p \mathrm{H}$ gave the highest concentration of hepatic folate, this method gave relatively low values with human liver.

Approximately $15 \mathrm{mg}$. of liver (accurately weighed) was placed in a small hand tissue-grinder containing $0.1 \mathrm{M}$ potassium phospate buffer $p \mathrm{H} 6$ with freshly added ascorbic acid ( $1 \mathrm{~g}$. to $100 \mathrm{ml}$.). One $\mathrm{ml}$. ascorbate buffer was used for every $2 \mathrm{mg}$. of liver ( 1 in 500). The liver suspension was frozen in dry ice-acetone and thawed on four occasions and the liver homogenized to provide a uniform suspension. The suspension was transferred to a screw-capped bottle and autoclaved at $116^{\circ} \mathrm{C}$. for 10 minutes. The suspension was filtered through No. 1 Whatman paper and the filtrate kept at $-20^{\circ}$ C. until assayed.

\section{Preparation of Liver Sample for Determination of Nature of Folate Compounds}

Four to five grammes of liver obtained at necropsy were homogenized in the cold in $200 \mathrm{ml}$. of freshly prepared ascorbate buffer ( $1 \%$ at $p \mathrm{H} 6)$ for five minutes. The slurry was heated at $55-61^{\circ} \mathrm{C}$. with vigorous stirring for 10 minutes and the temperature brought to $85^{\circ} \mathrm{C}$. with reduced stirring over a period of 10 minutes. The hot suspension was filtered rapidly through No. 1 Whatman paper and cooled. Five to six grammes of activated acid washed charcoal was added to the filtrate, stirred for one minute, and filtered. The charcoal was resuspended in $200 \mathrm{ml}$. absolute alcohol containing $1 \mathrm{ml}$. of concentrated ammonia and the suspension filtered. Mercaptoethanol $(0.5 \mathrm{ml}$. of a $10 \%$ solution) was added to the filtrate and the volume reduced to almost zero under reduced pressure. The final product was resuspended in approximately $5 \mathrm{ml}$. $0.5 \mathrm{M}$ phosphate buffer with $1 \%$ potassium ascorbate $p \mathrm{H}$ 7.2. The nature of the folate compounds was determined by column chromatography on DEAE-sephadex A50 with pure synthetic folate analogues as markers, as well as by microbiological assay with L. casei, P. cerevisiae, and Str. faecalis. Fractions were eluted from the column by gradient elution as described by Butterworth, Santini, and Frommeyer (1963).

Microbiological Assay.-Folate content of the liver samples and sera were assayed with $L$. casei, using the medium described by Toepfer, Zook, Orr, and Richardson (1951). One gramme of potassium ascorbate was added to every $500 \mathrm{ml}$. of medium. The liver filtrate was diluted between 20 - and 50-fold with ascorbate buffer for assay.

Serum Vitamin $B_{12}$.-Serum-vitamin $B_{12}$ levels were assayed using L. leichmannii as the test organism.

Urinary Formiminoglutamic Acid.-Urine was collected into a container with $1-2 \mathrm{ml}$. of $\mathrm{N}-\mathrm{HCl}$ and the formiminoglutamic-acid content estimated spectrophotometrically by the method of Chanarin and Bennett (1962).

\section{Results}

\section{Nature of Hepatic Folate in Man}

The folate compound obtained from liver supported the growth of $L$. casei only and was entirely inactive for Str. faecalis and P. cerevisiae.

Chromatography on DEAE-sephadex resulted in a single sharp peak of material with activity for $L$. casei only. Eighty per cent. of the microbiologically active material was recovered from the column.

When the fraction from the column showing activity of $L$. case $i$ was added to a solution of synthetic 5-methyltetrahydrofolate kindly supplied by the late Professor D. D. Woods and the mixture run on the column, the folate activity of the mixture was localized in the same single sharp peak. The hepatic-folate activity was distinct from pteroyltriglutamate, N 10-formylpteroylglutamic acid, N 5-formyltetrahydropteroylglutamic acid, and pteroylglutamic acid.

\section{Hepatic-folate Content}

The folate content of the liver samples varied from $0.7 \mu \mathrm{g} . /$ g. of liver to $17 \mu \mathrm{g} . / \mathrm{g}$. (Table and Fig. 1).

There appeared to be a good correlation between the hepatic folate and the urinary excretion of formiminoglutamic acid (Fig. 2). Thus, when the urinary excretion of formiminoglutamic acid was normal (less than $17 \mathrm{mg}$.) the hepatic folate was greater than $5 \mu \mathrm{g}$. $/ \mathrm{g}$. The excretion of urinary formiminoglutamic acid was increased in 10 cases, and in seven of these the hepatic folate was below $4 \mu \mathrm{g} . / \mathrm{g}$. The highest formiminoglutamic-acid excretion was generally found in the patients with the lowest hepatic-folate levels. In two patients with megaloblastic anaemia the hepatic folate was $1 \mu \mathrm{g} . / \mathrm{g}$. with markedly elevated urinary excretion of formiminoglutamic acid.

There was also an overall correlation between the levels of hepatic folate and serum folate (Fig. 3). However, one patient whose hepatic-folate level was $2.5 \mu \mathrm{g}$. $/ \mathrm{g}$. had a serum-folate level of $13 \mu \mathrm{mg} . / \mathrm{ml}$. The serum-folate level was below $5 \mu \mathrm{mg} . / \mathrm{ml}$. in 10 patients, and in six of these the hepaticfolate level was below $5 \mu \mathrm{g}$. $/ \mathrm{g}$.

All but one of the patients had normal haemoglobin levels, normal appearance of the stained blood films, and normal neutrophil nuclear lobulation. The one exception was a patient with disseminated carcinoma from a primary in the oesophagus who had an iron-deficiency anaemia. The two patients with 


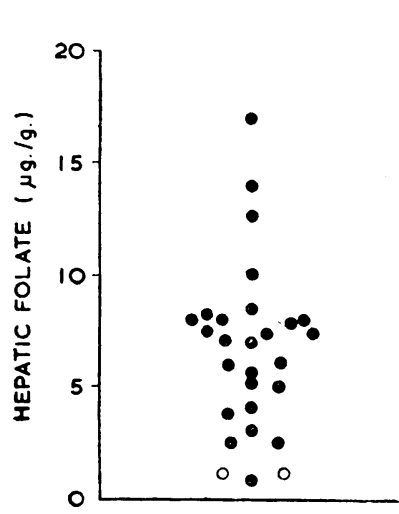

FIG. 1

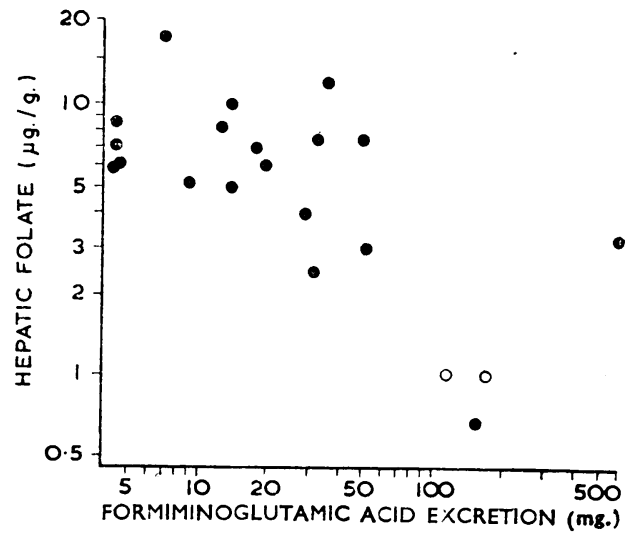

Fig. 2

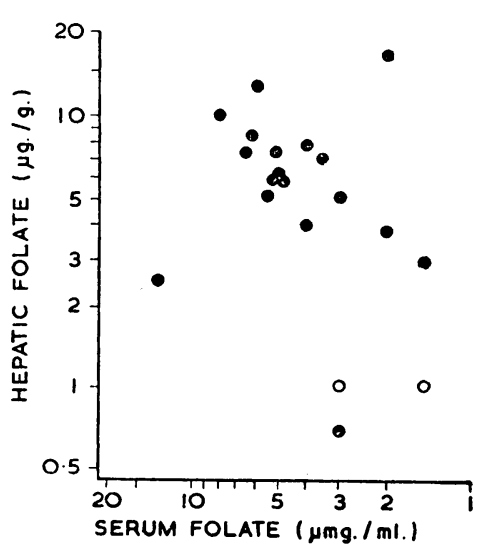

FIG. 3

FIG. 1.-Hepatic-folate levels in 26 patients undergoing laparotomy and in two patients with megaloblastic anaemia due to folic-acid deficiency (open circle). FIG. 2.-Correlation between hepatic-folate levels and urinary excretion of formiminoglutamic acid. Two patients with megaloblastic anaemia are designated by open circles. FIG. 3.- Correlation be tween hepatic-folate levels and serum-folate ( $L$. case $i$ ) concentration. Two patients with megaloblastic anaemia are designated by open circles.

megaloblastic anaemia due to folic-acid deficiency had low serum-folate levels, elevated urinary excretion of formiminoglutamic acid, and very low hepatic-folate levels. The patient with the lowest hepatic level $(0.7 \mu \mathrm{g} . / \mathrm{g}$.), however, appeared to be haematologically normal. This patient had hepatic cirrhosis.

A sternal-marrow aspiration was carried out on Case 19 whose formiminoglutamic-acid excretion was $570 \mathrm{mg}$., serum folate $2 \mu \mathrm{mg}$. $/ \mathrm{ml}$., and hepatic folate $3.7 \mu \mathrm{g} . / \mathrm{g}$. The marrow was morphologically normal.

\section{Discussion}

The present studies show that, as in the horse (Donaldson and Keresztesy, 1959), hepatic folate in man appears to be 5-methyltetrahydropteroylglutamic acid. The importance of this storage form of folic acid in the intermediary metabolism of the folate coenzymes has been reviewed by Buchanan (1964).

The results also show that abnormal results with tests which measure folic-acid function are usually associated with a reduced folate content of the liver.

The correlation between hepatic folate on the one hand and urinary excretion of formiminoglutamic acid after $15 \mathrm{~g}$. of histidine and serum-folate level on the other was good. In particular, a normal urinary excretion of formiminoglutamic acid was always accompanied by hepatic-folate values greater than $5 \mu \mathrm{g} . / \mathrm{g}$. This relationship does not hold in pregnancy and in patients receiving anticonvulsant drugs, and this has been discussed elsewhere (Chanarin, Rothman, and WatsonWilliams, 1963 ; Chanarin, 1965).

Since observations were made only on hospital patients, it is not possible to define a normal range for the folate content of the liver. Nevertheless, the wide range of values encountered suggests that a fall in the tissue content of folate may develop rapidly in ill subjects, and it is therefore not surprising that abnormal results with tests for folate function are frequent in such patients.

Three patients excreted increased amounts of formiminoglutamic acid in the urine, though the hepatic-folate levels were between 7 and $10 \mu \mathrm{g} . / \mathrm{g}$. Similarly four patients had reduced serum-folate levels ( 2 to $4 \mu \mathrm{mg}$. $/ \mathrm{ml}$.), though the hepatic folate levels were between 5 to $17 \mu \mathrm{g} . / \mathrm{g}$. These patients therefore show evidence of abnormal folate "function" not due to actual depletion of the folate content of the tissues. Such a mechanism has been postulated as the cause of the megaloblastic anaemia in patients receiving anticonvulsant drugs and in patients with other megaloblastic anaemias in whom none of the usual causative factors were found.
Low hepatic-folate values were found in two patients with megaloblastic anaemia. Nevertheless, the lowest value encountered was in a patient with a normal haemoglobin level and a normal blood film. Thus it is likely that folate deficiency alone is not the only factor required to induce megaloblastic haemopoiesis and that a further factor is often required to convert haemopoiesis from a normoblastic to a megaloblastic form. In the two cases of megaloblastic anaemia described in this paper alcohol was the important factor (Sullivan and Herbert, 1964). Possibly infection may act in a similar way.

\section{Addendum}

Recently Leevy, Baker, TenHove, Frank, and Cherrick (1965) have noted a good correlation between serum-folate levels and hepatic folate in alcoholic patients, and an equally good correlation in a small number of other patients (Leevy, Cardi, Frank, Gellene, and Baker, 1965).

\section{Summary}

The form of folic acid in the liver in man was 5 methyltetrahydrofolate.

The amount of folate in the liver of hospital patients undergoing laparotomy varied from 0.7 to $17 \mu \mathrm{g}$. $/ \mathrm{g}$. of liver. The urinary excretion of formiminoglutamic acid was always within the normal range when the hepatic-folate level was above $5 \mu \mathrm{g}$./ g. and was abnormally elevated when the level of hepatic folate fell below that level. Three patients had abnormally elevated urinary excretion of formiminoglutamic acid despite "normal" hepatic-folate levels.

There was also a satisfactory correlation between the hepaticfolate levels and the serum-folate ( $L$. casei) concentrations.

Two patients with megaloblastic anaemia due to folic-acid deficiency and excessive alcohol intake had hepatic-folate levels of $1 \mu \mathrm{g} . / \mathrm{g}$.

We wish to thank the surgical staff of St. Mary's Hospital, and in particular Professor W. T. Irvine and Mr. H. Eastcott, for providing us with liver biopsy specimens, and Dr. A. Buchanan for performing a percutaneous liver biopsy in two patients. We also wish to acknowledge our indebtedness to the late Professor D. D. Woods who kindly provided us with 5-methyl folate.

\section{REFERENCES}

Bennett, M. C., Berry, V., Chanarin, I., and Ardeman, S. (1964). F. clin. Path., 17, 27.

Butterworth, C. E., Santini, R., and Frommeyer, W. B. (1963). I clin Invest., 42, 1929. 
Buchanan, J. M. (1964). Medicine (Baltimore), 43, 697. Chanarin, I. (1964). Proc. roy. Soc. Med., 57, 384. Chanarin, 1. (1964). Proc. roy. Soc. Med. and Bennett, M. C. (1962). Brit. med. 7., 1, 27 Rothman, D., and Watson-Williams, E. J. (1963). Lancet, 1, 1068.

Donaldson, K. O., and Keresztesy, J. C. (1959). F. biol. Chem., 234, 3235

Herbert, V. (1964). Proc. roy. Soc. Med., 57, 377.
Leevy, C. M., Baker, H., TenHove, W., Frank, O., and Cherrick, G. R. (1965). Amer. Y. clin. Nutr., 16, 339

Cardi, L., Frank, O., Gellene, R., and Baker, H. (1965). Ibid., 17, 259.

Romine, M. K. (1960). F. Vitaminol., 6, 196. .

Sullivan, L. W., and Herbert, V. (1964). 7. clin. Invest., 43, 2048.

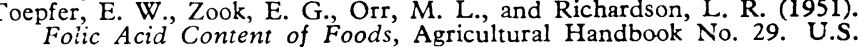
Department of Agriculture, Washington, D.C.

\title{
Value of the Vaginal Smear in the Investigation of Amenorrhoea
}

\author{
J. WILLIS,* M.D. ; J. M. G. HARLEY, $\dagger$ M.D., M.R.C.O.G.
}

Brit. med. F., 1966, 1, 399-401

The earliest suggestion that the examination of vaginal fluid may be used in the study of human ovarian function was made by Pouchet (1847). However, it was not until Papanicolaou (1933) published his classic monograph that the existence of cyclical changes in the epithelium of the human vagina and clinical hormonal cytology became established.

Since then a large volume of literature has appeared on vaginal-smear patterns before puberty, during adolescence, in pregnancy, and after the menopause. In addition, the vaginal smear has been extensively used in studying the effects of oestrogens, progesterone, and androgens on the vaginal epithelium. The literature on these subjects is too expansive for inclusion in this paper, but readers are referred to reviews by de Allende (1958), von Haam (1961), Rakoff (1961a, 1961b, 1962 ), and to symposia $(1957,1958 \mathrm{a}, 1958 \mathrm{~b}, 1959)$ in Acta Cytologica.

In contrast there is still a paucity of reports on vaginal cytology in specific gynaecological endocrinopathies, a fact commented upon by Rakoff (1961a, 1961b). In view of this it was thought desirable to analyse our material, and the results are now reported.

\section{Material and Methods}

The material under review is selective and consists of 107 patients, most of whom attended the gynaecological endocrine clinic at the Royal Victoria Hospital, Belfast. Selection was based on four criteria: (1) the amenorrhoea was either the presenting or one of the principle complaints and was of at least three months' duration; (2) the patient had not taken any hormone therapy for two months prior to or during the investigations ; (3) the cause of the amenorrhoea was established beyond reasonable doubt after complete clinical and laboratory investigations; and (4) vaginal smears were taken at weekly intervals for periods up to five weeks.

\section{Collection, Fixation, and Staining Methods}

The smears were prepared from cells obtained by lightly scraping the lateral wall of the upper third of the vagina, this being the optimal area for hormonal studies (Pundel, 1960 ; Soost, 1960 ; Wied, 1961). They were fixed immediately in a solution of equal parts $95 \%$ ethyl alcohol and ether and subsequently stained by slight modifications of either the Shorr (1941) or the Papanicolaou (1942) methods. The

\footnotetext{
* Department of Pathology, Queen's University of Belfast.

† Department of Obstetrics and Gynaecology, Queen's University of Belfast.
}

former technique is that recommended for endocrine investigations.

\section{Classification of the Epithelial Cells}

The epithelial cells in the smears were classified according to the nomenclature suggested as the result of a symposium (1958a, 1958b) on cytological terminology.

Superficial cells.-These are large polygonal cells with a completely pyknotic nucleus and either eosinophilic cytoplasm (eosinophilic karyopyknotic cells) or cyanophilic cytoplasm (cyanophilic karyopyknotic cells).

Intermediate Cells.-These are moderately large polygonal cells with a vesicular nucleus and usually cyanophilic but occasionally eosinophilic cytoplasm. In some instances where the nucleus is elongated or spindle-shaped it may appear hyperchromatic.

Parabasal Cells.-These are small round or oval cells with a large vesicular nucleus and cyanophilic cytoplasm.

\section{Classification of Cytological Curves}

The general appearances of the entire smear were first ascertained and then 500 epithelial cells over five different fields were counted in order to determine the percentages of each type of epithelial cell present, particularly the percentage of eosinophilic karyopyknotic cells. In the absence of inflammation and other factors altering the $\mathrm{pH}$ of the vagina, these latter cells were taken to represent full maturation of the vaginal epithelium and thus oestrogenic production. The percentages of eosinophilic karyopyknotic cells in each of the weekly smears were then plotted graphically and the curves obtained were representative of the degree of oestrogenic effect during the period under consideration. The different types of curves encountered are as follows:

Hypertrophic.-This curve indicates the existence of persistently high oestrogen secretion as evidenced by the high percentage (40 or more) of eosinophilic karyopyknotic cells in all or the majority of smears in each series.

Eutrophic.-This curve is evidence of normal oestrogen production and displays variation in the percentages of eosinophilic karyopyknotic cells from week to week, starting off with low levels, gradually increasing to a peak of $40 \%$ or more towards the middle of the cycle, and then decreasing again. Such criteria would, of course, be inadequate for determining whether or not ovulation had occurred, but this is not a consideration of the present study. 